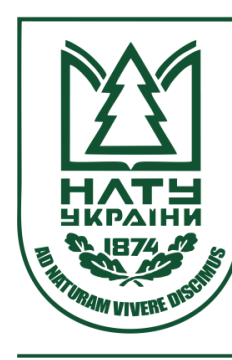

Науковий вісник НЛтУ України Scientific Bulletin of UNFU

ISSN 1994-7836 (print)

http://nv.nltu.edu.ua

https://doi.org/10.15421/40280514

$@ \bowtie$ Correspondence author

Article received 11.05.2018 p.

Article accepted 31.05.2018 p.

U. B. Bashutska

ulyana_b@ukr.net

Удк 628.474.[3+38]:66.074.3(430.127)

У. Б. Башуцька

Національний лісотехнічний університет Украӥни, м. Львів, Украӥна

\title{
ОТРИМАННЯ ЕНЕРГІЇ СПАЛЮВАННЯМ ВІДСОРТОВАНОГО СМІТТЯ НА СПЕЦІАЛІЗОВАНОМУ ПІДПРИЄМСТВІ (ДОСВІД НІМЕЧЧИНИ)
}

\begin{abstract}
Проаналізовано метод отримання теплової й електричної енергії з відсортованого сміття на спеціалізованому підприємстві у південно-західній частині Німеччини. Електростанція міста Штутгарт отримує енергію із відходів та вугілля (сміттєспалювальний завод-теплоелектроцентраль у Мюнстері й теплоелектроцентраль у Гайсбургу). Загалом "ШтутгартМюнстер" продукує 183 МВт електричної потужності й 450 МВт теплової потужності. Пропускна спроможність спалювання відходів становить 420000 т/рік (теплотвірна здатність - 11000 КДж/кг). Здійснено порівняння викидів основних забруднювальних речовин у атмосферне повітря після застосування таких природоохоронних технологій, як: каталітичне очищення від оксидів Нітрогену та руйнування діоксинів, вилучення пилу електростатичним фільтром; чотиристадійне скруберне очищення повітря від $\mathrm{HCl}, \mathrm{HF}, \mathrm{SO}_{2}$, дуже дрібнодисперсного пилу, важких металів, поліхлорованих дибензофуранів. Відзначено важливість спалювання непридатних для перероблення відходів для вирішення актуальної для України проблеми переповнення офіційних полігонів, а також необхідність чіткого дотримання таким підприємством екологічних нормативів, використання найсучасніших систем очищення та захоронення продуктів згоряння, побічного виробництва енергії.
\end{abstract}

Ключові слова: відсортоване сміття; енергія; спалювання; викид; природоохоронні технології.

Вступ. Зростання рівня споживання населенням різноманітних видів продукції супроводжується утворенням значної кількості відходів. В Україні збільшуються обсяги нагромадження відходів, кількість полігонів та звалищ для їх захоронення, погіршується санітарний стан населених пунктів. Згідно з даними (Maksymenko et al., 2016), в Україні нагромаджено 36 млрд т відходів, 3 яких утилізується лише $30 \%$ промислових відходів і 4 \% побутових відходів.

Тривалий час сміття у Німеччині не мало жодної цінності - його спалювали, складували, закопували поки уряд ФРН не спонукав підприємства до вторинного перероблення сміття, а громадян - сортувати відходи. У 1991 р. було розроблено приписи щодо пакування. Закон покладав на кожного виробника відповідальність за його продукт також після споживання. Промисловість після цього заснувала свою систему збирання та повторного перероблення сміття, яку назвали "дуальною системою". ІІї розпізнавальним знаком став символ кругообігу - "зелена крапка". Його ставлять на всіх продуктах, які беруть участь у системі ресайклінгу (Hroshi zi smittia, 2017). У Німеччині починають сортувати відходи, оскільки їх більшу частину можна вигідно утилізовувати за умови сумлінного сортування безпосередньо у місці утворення (подвір'я житлових та адміністративних будинків). 3 порядком сортування та умовами поводження із відходами мешканці Німеччини ознайомлюються на інтернет-сайті районної (міської) адміністрації (Froidenshtadt, 2018). Система роздільного збирання відходів забезпечує вилучення корисних складників (паперу, скла, пластику), перероблення органічних відходів у метантенку (метанове зброджування за допомогою бактерій-мінералізаторів), перероблення садової біомаси в компост, безкоштовне здавання користованого одягу й взугтя, а також великогабаритних речей, вказуються адреси магазинів торгівлі вживаними речами. При цьому утворюється частина відсортованих відходів, яка $є$ непридатною ні для вторинного використання, ні для органічного розкладу. Цей залишок називають "рестмюль" (Restmüll) і спалюють його на спеціалізованому підприємстві. Таку функцію у південно-західній частині Німеччини виконує електростанція Штутгарта, отримуючи цінну енергію із відходів та вугілля.

Раціональне природокористування для сталого розвитку. Підприємство складається із сміттєспалювального заводу-теплоелектроцентралі у Мюнстері та теплоелектроцентралі в Гайсбургу. Основним завданням сміттєспалювального заводу $є$ не виробництво електроенергії, а спалювання відходів і забезпечення централізованого теплопостачання. Для ефективного використання палива у Штутгарт-Мюнстері одночасно здійснюється виробництво електричної та теплової енергії. Виробничий процес забезпечують вугільна електростанція із трьома котлами, сміттєспалювальна станція із трьома котлами для спалювання сміття (Restmüll), непридатного для інших видів перероблення, трьох парових турбін і однієї газотурбінної установки (рис.). Загалом "Штутгарт-Мюнстер" продукуе 183 МВт електричної потужності й 450 МВт теплової

Інформація про авторів:

Башуцька Уляна Богданівна, канд. с.-г. наук, доцент, кафедра екології. Email: ulyana_b@ukr.net

Цитування за ДСту: Башуцька У. Б. Отримання енергії спалюванням відсортованого сміття на спеціалізованому підприємстві (досвід Німеччини). Науковий вісник НЛтУ України. 2018, т. 28, № 5. С. 65-68.

Citation APA: Bashutska, U. В. (2018). Producing of energy by burning sorted wastes on the specialized power plant (experience of Germany). Scientific Bulletin of UNFU, 28(5), 65-68. https://doi.org/10.15421/40280514 
потужності. У 2007 р. інвестиції у сумі 110 млн євро дали змогу ввести в експлуатацію два запасних котли для спалювання відходів. Пропускна спроможність спалювання відходів становить $420000 \mathrm{~T} /$ рік (теплотвірна здатність - 11000 КДж/кг). Отже, забезпечується екологічно відповідальна й економічно доцільна утилізація відходів у Баден-Вюртемберг. 3 цією метою місто Штутгарт і райони Есслінген і Ремс-Мур у квітні

$$
\text { Бункер }
$$

загального сміття, розвантажувальне приміщення
Спалювання і Пиловловлення генерування тепла

Пароутворення

\section{Е-фільтр}

\section{Posin}

$$
\text { во }
$$

2003 р. підписали контракт із управління відходами 3 енергетичним концерном "Енергія Баден-Вюртемберг". Відповідно до угоди, місто Штутгарт і два райони щорічно доставляють на завод у Мюнстері 225000 т залишкового сміття. Інші 185000 т надходить від компаній округу, з якими підписано відповідні договори (Primärenergie veredeln, 2010).

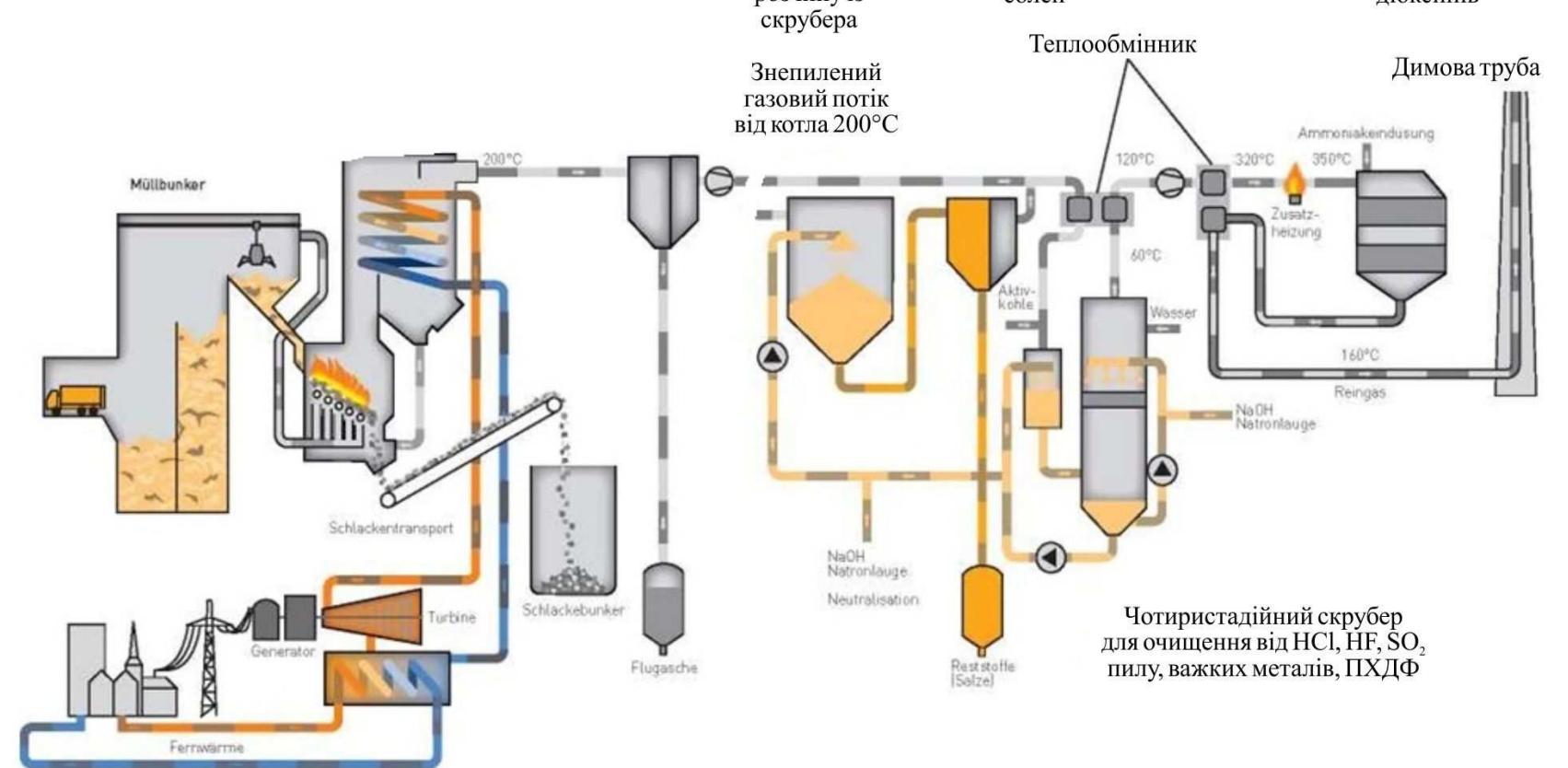

Рисунок. Функціональна схема сміттєспалювального підприємства (Primärenergie veredeln, 2010)

Енергетичний концерн EnBW дотримується у своїй діяльності принципів сталого розвитку, які передбачають екологічну, економічну, а також суспільну відповідальність. Це $є$ перший німецький енергетичний концерн, який прийняв систему екологічного менеджменту, сертифіковану ISO 14001, і розвинув іiї у наступні роки. Впровадження цієї сертифікації $є$ добровільним і показує важливість питання захисту навколишнього середовища від надмірних антропогенних навантажень. Центральним елементом ISO $14001 \epsilon$ неперервне покращення якості навколишнього природного середовища, раціональне природокористування. Для цього підприємство дотримується встановлених нормативів навантаження на атмосферне повітря і воду (EnBW, 2016; Dovkillia, 2015). За допомогою системи акумуляції тепла відхідне тепло від генерування електроструму використовують для обігріву будівель і як енергію для виробничого процесу. Це дає змогу раціонально використовувати природний ресурс та уникати надмірних антропогенних навантажень на клімат (Gaisburg, 2018). Підприємство розташоване й функціонує в околиці Штутгарта, забезпечуючи домогосподарства теплопостачанням відповідно до принципів раціонального природокористування.

Функціонування системи "віддаленого тепла". Електростанції способом спалювання горючих копалин забезпечують вироблення електричного струму. Спеціалізоване на спалюванні "залишкового" сміття під- приємство $є$ теплоелектроцентраллю, продукуючи електрострум і теплову енергію. Робота забезпечується такими станціями:

Станція 1: Газові турбіни. Відділення газових турбін забезпечує додаткові потужності енергетичних резервів, зокрема для гарантування безперебійного постачання струму, для покриття підвищених енергетичних потреб способом спалювання рідкого палива.

Станція 2: Пункт управління. $€$ "серцем" теплоелектростанції. Із нього керуються всі процеси виробничих систем, а також здійснюється їх відеоспостереження. Усі етапи технологічних процесів $\epsilon$ повністю автоматизованими. Спостерігають за ними через великі монітори. Додаткові монітори призначено для спостереження за процесом спалювання сміття у котлі, оскільки сміття горить не завжди однаково. Для цього також у центрі управління $\epsilon$ встановлена додаткова спостережна башта.

Станція 3: Бункер загального сміття, розвантажувальне приміщення. Бункер загального сміття має ємність $18000 \mathrm{~m}^{3}$. Багатошарові ванни запобігають виходу із сміття можливих шкідливих речовин, що в ньому містяться. Постачання сміття відбувається у спеціальне замкнене розвантажувальне приміщення для запобігання й уникнення запахів, шуму та викидів пилу.

Станція 4: Пункт керування вантажопідйомним краном. За допомогою грейфера відходи з розвантажувального приміщення перемішуються і постачаються до 
роторного подрібнювача. Подрібнене сміття стрічковим транспортером постачається у котел для спалювання. У цьому пункті здійснюється керування краном та спостереження за подрібненням і транспортуванням сміття.

Станція 5: Котел для спалювання. У котлі під час постачання повітря відбувається спалювання відходів на вогнестійкій решітці за температури між $900 \mathrm{i}$ $1100{ }^{\circ} \mathrm{C}$. Отримане під час спалювання тепло використовують для утворення нагрітої пари $500^{\circ} \mathrm{C}$ та під тиском 60 бар. Вугільний та сміттєвий котли постачають пару у спільний парозбірник. Звідти пара направляється до турбін і використовується для вироблення струму й тепла.

Станція 6: Очищення відхідних газів. Під час спалювання сміття утворюються відхідні гази, які містять забруднювальні речовини, що були характерними для сміття. Відбувається їх очищення перед викидом із 180метрової димової труби. Пил, що міститься у газоповітряному потоці, вилучається електрофільтрами на виході 3 котла спалювання. За допомогою газопромивного обладнання, що складається із апаратів мокрого газоочищення і каталітичного очищення, забруднювальні речовини вимиваються із газоповітряного потоку і вилучаються у вигляді сухих солей. Солі та вилучений пил щоденно утилізуються.

Станція 7: Парова турбіна і генератор. Енергія пари у паровій турбіні перетворюється на обертову енергію, у генераторі - в електричну. Пара вилучається із турбіни під тиском 5,5 бар та 0,9 бар для продукції тепла. За допомогою такого об'єднаного утворення струму й тепла оптимально використовують спалювальну сировину.

Станція 8: "Віддалене тепло". Підприємство постачає "віддалене тепло" в окрузі тепломережі протяжністю 275 км, обслуговуванням якої займається енергетичний концерн "EnBW". Основними забруднювальними речовинами (табл.), що містяться у відхідних газоповітряних потоках, є оксиди Нітрогену $\left(\mathrm{NO}_{\mathrm{x}}\right)$, частки у вигляді суспензій (леткий пил) і Сульфур (IV) оксид $\left(\mathrm{SO}_{2}\right)$. Для їх вилучення відбувається нітрогенування, знепилення, сульфурування.

Таблиця. Викиди забруднювальних речовин енергетичним концерном (Primärenergie veredeln, 2010)

\begin{tabular}{|c|c|c|c|}
\hline Рік & $\begin{array}{c}\mathrm{SO}_{2}, \text { мг/КВт } \cdot \\
\text { год }\end{array}$ & $\begin{array}{c}\mathrm{NO}_{\mathrm{x}}, \mathrm{мг} / \mathrm{KBT} \cdot \\
\text { год }\end{array}$ & $\begin{array}{c}\mathrm{CO}_{2}, \text { г/КВт } \\
\text { год }\end{array}$ \\
\hline 2004 & 150 & 145 & 225 \\
\hline 2005 & 170 & 170 & 250 \\
\hline 2006 & 140 & 165 & 240 \\
\hline 2007 & 140 & 173 & 254 \\
\hline 2008 & 131 & 158 & 235 \\
\hline 2009 & 156 & 159 & 241 \\
\hline $\mathrm{H}-2008^{*}$ & 280 & 400 & 506 \\
\hline
\end{tabular}

Примітка: " порівняльні дані Державного об'єднання енергетичного і водного господарства (BDEW).

Нітрогенування. Оксиди Нітрогену відхідного газу утилізуються за допомогою аміаку $\left(\mathrm{NH}_{3}\right) 3$ каталізатором (ванадій чи титан) до азоту $\left(70 \% \mathrm{~N}_{2}\right)$ й води $\left(\mathrm{H}_{2} \mathrm{O}\right)$. Отже, вдається зменшити вміст $\mathrm{NO}_{\mathrm{x}}$ на $90 \%$. Одночасно руйнуються діоксини.

Знепилення. Частинки пилу вилучаються із газоповітряного потоку електростатичним фільтром: зарядження завислих у газі частинок; рух заряджених час- тинок до електродів; осадження частинок на електродах і видалення частинок 3 електродів. Напруга між електродами становить від 40000 до 60000 В. Отже, вилучається 99,9 \% пилу з газопилового потоку. Решта видаляється із очищеним повітрям і є настільки незначною, що не обліковується. Весь попіл застосовують у будівельній промисловості.

Сульфурування. Під час методу газопромивання сульфуровмісні відхідні гази пропускаються через "вапняне молоко" (подрібнене вапно - силосний бак ємність із вапняною суспензією - повітря для окиснення - абсорбер - газопромивання в абсорбері - (технологічна вода) - $з$ абсорбера на гідроциклон - фільтрат знову до абсорбера - гіпс у бункері). При цьому відбувається зв'язування діоксиду Сульфуру з кальцій карбонатом із утворенням карбон (IV) оксиду та кальцій сульфату у вигляді гіпсу, який потім утилізується як будівельний матеріал. Ступінь вилучення $\mathrm{SO}_{2}$ перевищує $90 \%$. Чотиристадійне скруберне очищення забезпечує також вилучення $\mathrm{HCl}, \mathrm{HF}, \mathrm{SO}_{2}$, дуже дрібнодисперсного пилу, важких металів, поліхлорованих дибензофуранів.

Очищені гази викидаються через 180-метрову димову трубу. Підприємство EnBW безперервно здійснює виміри та реєстрацію концентрації забруднювальних речовин у відхідних газах. Результати замірів додатково пересилаються онлайн спостережним органам влади. Такий подвійний екологічний моніторинг називають "скляною димовою трубою".

Висновки та узагальнення. Сміттєспалювання, як кінцевий етап знищення тих відходів, котрі непридатні для перероблення, дає змогу уникнути проблем переповнення офіційних полігонів і $є$ виправданим за умови чіткого дотримання всіх необхідних нормативів, використання сучасних систем очищення та раціонального захоронення продуктів згоряння, побічного виробництва енергії з метою раціонального використання природних ресурсів, а також поки не буде винайдено нових безпечніших методів знищення відходів.

\section{Перелік використаних джерел}

Dovkillia. (2015). Ofitsiinyi internet-sait Federalnoho vidomstva z pytan dovkillia. Retrieved from: http://www.umweltbundesamt.de. [In Ukrainian].

EnBW. (2016). Ofitsiinyi internet-sait kontsernu EnBW. Retrieved from: http://www.enbw.com. [In Ukrainian].

Froidenshtadt. (2018). Ofitsiinyi internet-sait rady okruhu Froidenshtadt. Retrieved from: http://www.landkreis-freudenstadt.de. [In Ukrainian].

Gaisburg. (2018). Heizkraftwerk Stuttgart, Betriebsstelle Münster, Betriebstelle Gaisburg. Retrieved from: https://www.enbw.com/media/konzern/docs/energieerzeugung/enbw flyer_stuttgart_muenster_gaisburg.pdf

Hroshi zi smittia. (2017). Yak Nimechchyna stala chempionom svitu z pereroblennia vidkhodiv. Retrieved from: http://www.dw.com. [In Ukrainian].

Maksymenko, N. V., Vladymyrova, O. H., Shevchenko, A. Yu., \& Kochanov, E. O. (2016). Normuvannia antropohennoho navantazhennia na navkolyshnie seredovyshche. Kharkiv: KhNU im. V. N. Karazina. 264 p. [In Ukrainian].

Primärenergie veredeln. (2010). Die fossil befeuerten Kraftwerke der EnBW. Sommer Corporate Media, Weiblingen, ISBA: B.2566.1012. 


\section{ПОЛУЧЕНИЕ ЭНЕРГИИ СЖИГАНИЕМ ОТСОРТИРОВАННОГО МУСОРА НА СПЕЦИАЛИЗИРОВАННЫХ ПРЕДПРИЯТИЯХ (ОПЫТ ГЕРМАНИИ)}

Проанализирован метод получения тепловой и электрической энергии с отсортированного мусора на специализированном предприятии в юго-западной части Германии. Электростанция города Штутгарт получает энергию из отходов и угля (мусоросжигательный завод-теплоэлектроценталь в Мюнстере и теплоэлектроцентраль в Гайсбурге). Всего "ШтутгартМюнстер" производит 183 МВт электрической мощности и 450 МВт тепловой мощности. Пропускная способность сжигания отходов составляет 420000 т/год (теплотворная способность - 11000 кДж/кг). Проведено сравнение выбросов основных загрязняющих веществ в атмосферный воздух после применения таких природоохранных технологий, как каталитическая очистка от оксидов азота и разрушения диоксинов, извлечения пыли электростатическим фильтром, четырехэтапная скруберная очистка воздуха от $\mathrm{HCl}, \mathrm{HF}, \mathrm{SO}_{2}$, очень мелкодисперсной пыли, тяжелых металлов, полихлорированных дибензофуранов. Отмечена важность сжигания непригодных для переработки отходов для решения актуальной для Украины проблемы переполнения официальных полигонов, а также необходимость четкого соблюдения таким предприятием экологических нормативов, использование самых современных систем очистки и захоронения продуктов сгорания, побочного производства энергии.

Ключевые слова: отсортированный мусор; энергия; сжигание; выброс; природоохранные технологии.

U. B. Bashutska

Ukrainian National Forestry University, Lviv, Ukraine

\section{PRODUCING OF ENERGY BY BURNING SORTED WASTES ON THE SPECIALIZED POWER PLANT (EXPERIENCE OF GERMANY)}

The increase in consumption of various products is accompanied by the formation of a significant amount of wastes. Most of the wastes can be beneficial to utilize. To do this, they need to carefully sort directly at the site of formation (yards of residential and office buildings). Separate collection system provides extraction of useful components (paper, glass, plastic) for recycling. Such sort of system sent for recycling organic wastes into methane tanks, processing of biomass in the garden compost, free delivery of used clothes and shoes, as well as for heavy things. On content sites materials are specified addresses of shops trading second-hand things. There wastes that are unsuitable for recycling or organic decomposition are sorted. This balance is called Restmüll. It is burned in a specialized company which provides application of environmental technologies and equipment for environmental protection according to qualitative and quantitative indicators of its components normative value. This company operates in the south western part of Germany and performs at power plant of Stuttgart. It produces valuable energy from wastes and coal. It consists of a waste incineration plant in Münster and power plant in Gaisburg. The main objective of incinerator is burning wastes and providing district heating. For efficient use of fuel in Stuttgart-Münster production of electricity and heat is simultaneously carried out. The manufacturing process ensures coal power plant with three boilers, wastes incineration plant with three boilers to burn wastes, unsuitable for other types of processing, three steam turbines and a gas turbine. Stuttgart-Münster produces $183 \mathrm{MW}$ of electrical power and $450 \mathrm{MW}$ of thermal power. Consequently, waste incineration is performed as a final stage of destruction of wastes, which are unsuitable for processing, to avoid problems of overcrowding official landfills. Wastes incineration is justified. Strict compliance with all required standards is guaranted, the use of advanced wastewater disposal and efficient combustion products, energy production is provided.

Keywords: sorted wastes; energy; burning; emissions; environmental technologies. 